\title{
Rhipicephalus (Boophilus) microplus in the western-central region of Rio Grande do Sul, Brazil: multiresistant tick
}

Rhipicephalus (Boophilus) microplus na região centro-ocidental rio-grandense - Multirresistência acaricida

Fabrício Amadori Machado ${ }^{1}$; Felipe Lamberti Pivoto ${ }^{2 *}$; Maiara Sanitá Tafner Ferreira ${ }^{1}$;

Fabiano de Vargas Gregorio ${ }^{3}$; Fernanda Silveira Flores Vogel ${ }^{1}$; Luís Antônio Sangioni ${ }^{1}$

\author{
${ }^{1}$ Laboratório de Doenças Parasitárias, Departamento de Medicina Veterinária Preventiva, Universidade Federal de Santa \\ Maria - UFSM, Santa Maria, RS, Brasil \\ ${ }^{2}$ Clínica de Medicina de Ruminantes, Departamento de Clínica de Grandes Animais, Universidade Federal de Santa Maria - UFSM, \\ Santa Maria, RS, Brasil \\ ${ }^{3}$ Topographia e Planejamento Rural, Santa Maria, RS, Brasil
}

Received April 23, 2014

Accepted June 27, 2014

\begin{abstract}
The aim of the present study was to assess the acaricide resistance of tick populations in the western-central region of Rio Grande do Sul (Brazil), which has not previously been reported. Fifty-four cattle farms were visited and specimens of Rhipicephalus (Boophilus) microplus were collected and subjected to the adult immersion test, using nine commercial acaricides in the amidine, pyrethroid and organophosphate groups. Climatic data, including monthly precipitation, were recorded. The results from the present study demonstrated that seven of the acaricides analyzed presented mean efficacy values of less than $95 \%$, with large differences among the products tested. Nine of them exhibited satisfactory and unsatisfactory acaricide results on at least one farm. In conclusion, the farms located in the western-central region of Rio Grande do Sul, Brazil, exhibited populations of $R$. (Boophilus) microplus with variable degrees of susceptibility to different acaricides, thus suggesting that resistance to the active compounds exists. It is suggested that treatment protocols should be implemented at the beginning of winter and summer, using the acaricides that showed efficacy in the adult immersion test.
\end{abstract}

Keywords: Rhipicephalus (Boophilus) microplus, climatic variation, acaricide resistance, efficacy test.

\section{Resumo}

O objetivo deste estudo foi o de aferir a situaçáo da resistência dos produtos acaricidas utilizados no controle de carrapatos de bovinos, na mesorregiáo centro-ocidental rio-grandense. Para isso, cinquenta e quatro propriedades foram visitadas, e as teleóginas de Rhipicephalus (Boophilus) microplus foram coletadas e submetidas ao teste de eficácia acaricida in vitro, sendo utilizados nove produtos comerciais, pertencentes às classes químicas das amidinas, piretroides e organofosforados. Além disso, os dados das temperaturas máximas e mínimas médias e da precipitação acumulada foram compilados no período estudado. Os resultados demonstraram que sete produtos analisados apresentaram eficácia inferior a 95\%, com grande disparidade dos resultados. Nove produtos testados apresentaram satisfatória e não satisfatória eficácia em pelo menos uma propriedade analisada. Neste contexto, concluiu-se que as propriedades da mesorregiáo centro-ocidental rio-grandense apresentam cepas de $R$. (B.) microplus com graus variáveis de susceptibilidade a diferentes acaricidas, sugerindo, assim, que a resistência aos princípios ativos existe. Sugere-se a adoção de protocolos de tratamento acaricida no início do inverno e do verão, com a escolha do produto a ser utilizado baseado nos resultados do teste de eficácia acaricida.

Palavras-chave: Rhipicephalus (Boophilus) microplus, alterações climáticas, resistência acaricida, teste de eficácia.

\footnotetext{
*Corresponding author: Felipe Lamberti Pivoto

Clínica de Medicina de Ruminantes, Departamento de Clínica de Grandes

Animais, Hospital Veterinário Universitário, Universidade Federal de Santa

Maria - UFSM, Avenida Roraima, 1000, Bairro Camobi, CEP 97105-900,

Santa Maria, RS, Brasil

e-mail: felipe.pivoto@gmail.com
} 


\section{Introduction}

Cattle-rearing is one the main economic activities in Brazil and the south of the country is an important region for this activity. The state of Rio Grande do Sul has significant agricultural activity with a herd of about 14.5 million cattle (ANUALPEC, 2012). This Brazilian state is composed of seven regions with different mean temperature, relative humidity, accumulated rainfall and rainfall distribution (BECKER et al., 2012). These climatic variations may influence environmental contamination by parasites such as Rhipicephalus (B.) microplus ticks (SANTARÉM; SARTOR, 2003).

This cattle tick is considered to be a major threat to cattle production in tropical areas, causing economic losses, reducing productivity and increasing the cost of production through control measures (JONSSON, 2006). Moreover, $R$. (B.) microplus is the vector of agents of the tick fever complex, which causes economic losses worth US\$ 1,623,000.00 (ALMEIDA et al., 2006).

Control over $R$. (B.) microplus has been sought through excessive use of chemical compounds (ROCHA et al., 2011b). Currently, information about the epidemiology of this tick species is not taken into consideration by farm owners when choosing treatments (ROCHA et al., 2011a), and this is likely to accelerate the development of parasite resistance (FARIAS et al., 2008; GOMES et al., 2011; GUERRERO et al., 2012). In addition, new drug development is expensive and it is difficult to discover new molecules with satisfactory effectiveness (GRAF et al., 2004). Therefore, correct use of commercial acaricides is very important and tick control should be based on the epidemiological features of each region. Such measures may prolong the useful life of acaricides (WALL, 2007).

Different techniques have been developed to assess acaricide efficacy (SABATINI et al., 2001; KLAFKE et al., 2006; CASTROJANER et al., 2009; LOVIS et al., 2011). These include the adult immersion test (DRUMMOND et al., 1973), which makes it possible to implement appropriate measures for controlling this tick species.

In view of the significance of cattle-rearing in Rio Grande do Sul and the locally different environmental conditions that allow development of $R$. (B.) microplus, the aim of the present study was to assess the acaricide resistance in tick populations in the western-central region of Rio Grande do Sul (Brazil), which has not previously been reported.

\section{Materials and Methods}

\section{Study area}

The present study was conducted between 2009 and 2013, on 54 beef cattle farms with suspected acaricide resistance. The farms were located in 14 municipalities in the western-central region of Rio Grande do Sul, Brazil. The following municipalities were included: Cacequi (4 farms); Dilermando de Aguiar (4); Jari (2); Julio de Castilhos (4); Pinhal Grande (1); Restinga Seca (3); Santa Maria (8); Santiago (5); São Martinho da Serra (8); São Pedro do Sul (6); São Sepé (2); São Vicente do Sul (3); Tupanciretã (3) and Unistalda (1) (Figure 1).

\section{Tick collection}

Engorged females of Rhipicephalus (B.) microplus were collected manually from naturally infested cattle, at least 60 days after the last acaricide treatment. The specimens were stored in thermal boxes and were transported to the Parasitic Diseases Laboratory of the Federal University of Santa Maria, where they were kept under refrigeration at $4{ }^{\circ} \mathrm{C}$ (for a maximum period of 48 hours) until the in vitro test assay.

\section{Acaricides}

The selection of acaricides to be used in each in vitro test was based on the number of engorged females collected and the most recent products used on each farm. The acaricide products used were the following: amitraz $(0.250 \mathrm{mg} / \mathrm{mL}$; amidine); cypermethrin ( $0.150 \mathrm{mg} / \mathrm{mL}$; pyrethroid); amitraz $(0.500 \mathrm{mg} / \mathrm{mL})$; amitraz $(1 \mathrm{mg} / \mathrm{mL})+$ chlorpyrifos $(1 \mathrm{mg} / \mathrm{mL}$; organophosphate); cypermethrin $(0.188 \mathrm{mg} / \mathrm{mL})+$ citronellal $(0.013 \mathrm{mg} / \mathrm{mL})+$ chlorpyrifos $(0.313 \mathrm{mg} / \mathrm{mL}) ;$ cypermethrin $(0.080 \mathrm{mg} / \mathrm{mL})+$ ethion $(0.600 \mathrm{mg} / \mathrm{mL})$; cypermethrin $(0.125 \mathrm{mg} /$ $\mathrm{mL})+$ dichlorvos $(1.125 \mathrm{mg} / \mathrm{mL}$; organophosphate); cypermethrin $(0.188 \mathrm{mg} / \mathrm{mL})+$ citronellal $(0.013 \mathrm{mg} / \mathrm{mL})+$ chlorpyrifos $(0.313 \mathrm{mg} / \mathrm{mL})+$ piperonyl butoxide $(0.188 \mathrm{mg} / \mathrm{mL}$; pyrethroid $)$ and chlorpyrifos $(0.825 \mathrm{mg} / \mathrm{mL})+$ cypermethrin $(0.099 \mathrm{mg} / \mathrm{mL})$.

\section{In vitro assay}

The acaricide efficacy test was performed as described by Drummond et al. (1973). The specimens were divided according to macroscopic characteristics (integrity of body, level of engorgement and motility). The ticks were washed with distilled water, dried on filter paper, weighed and separated into groups containing ten specimens each (maximum weight difference was $\pm 0.5 \mathrm{~g}$ ).

Each test group was immersed in acaricide emulsion $(20 \mathrm{~mL})$ and remained under constant agitation for five minutes. For each test, a control group was immersed in distilled water $(20 \mathrm{~mL})$. The specimens were then dried on filter paper and dorsally fixed, using double-sided tape, in Petri dishes. Finally, they were stored in an incubator under controlled conditions $\left(27^{\circ} \mathrm{C}\right.$ and $80 \%$ relative humidity) for 14 days, so that oviposition could take place. After this period, the resultant eggs were weighed, separated into groups of $0.3 \mathrm{~g}$ and placed in individual glass vials. The vials were identified, sealed with a cotton plug and kept in the incubator under controlled conditions (see above) for 26 days, to assess the hatching process and estimate the reproductive parameters. The efficiency of the acaricides was determined based on the formula proposed by Drummond et al. (1973).

$\mathrm{RE}=$ (egg weight $\mathrm{X} \%$ egg hatching $\mathrm{X}$ 20000) / engorged female weight

$\mathrm{RE}=$ Reproductive efficiency

$\mathrm{AE}=(\mathrm{RE}$ of control group $-\mathrm{RE}$ of treated group $\mathrm{X} 100) /$ $\mathrm{RE}$ of control group

$\mathrm{AE}=$ Acaricide efficiency 


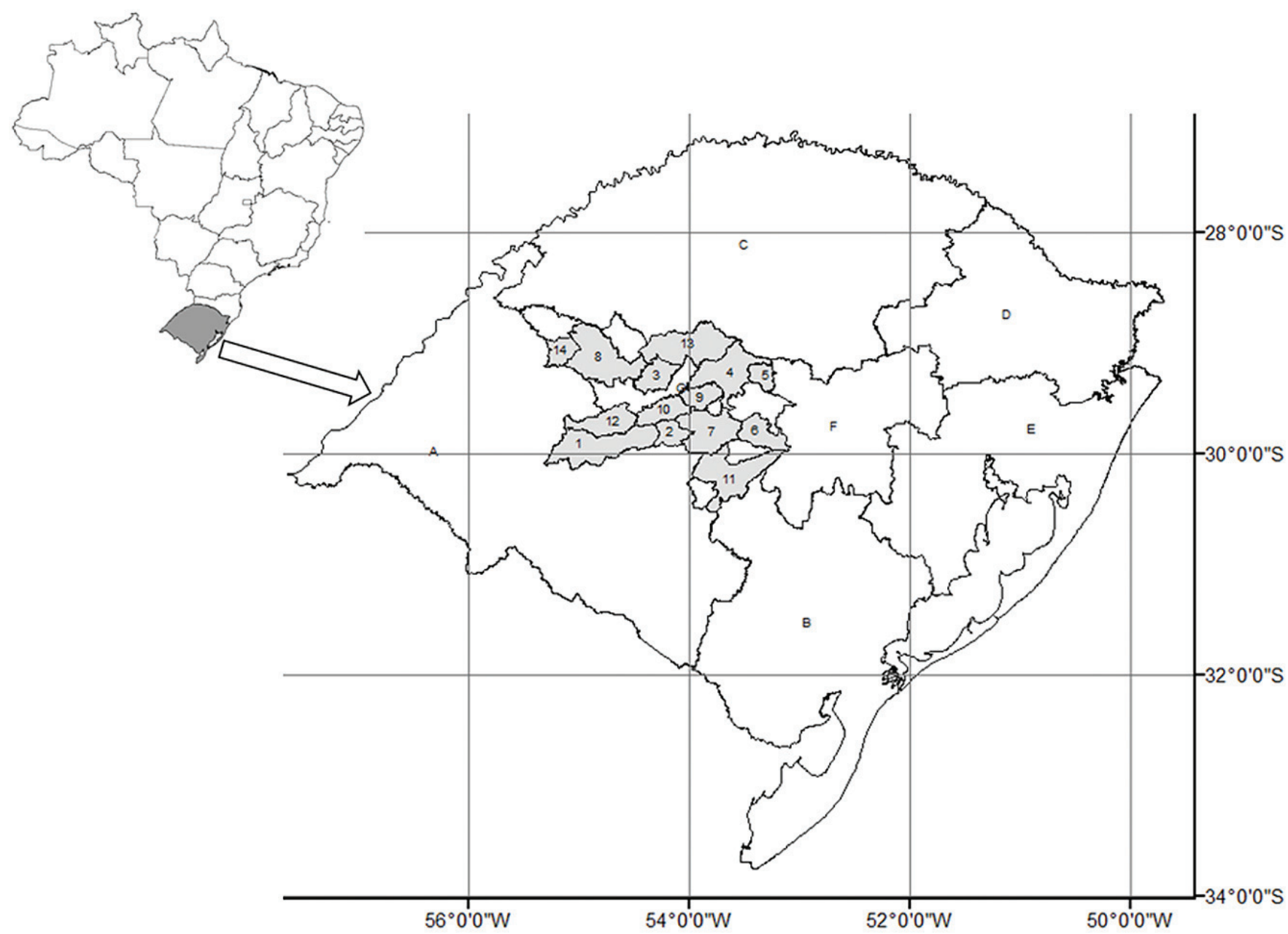

Figure 1. Geographical location of the western-central region of Rio Grande do Sul, Brazil. Cacequi (1); Dilermando de Aguiar (2); Jari (3); Júlio de Castilhos (4); Pinhal Grande (5); Restinga Seca (6); Santa Maria (7); Santiago (8); São Martinho da Serra (9); São Pedro do Sul (10); São Sepé (11); São Vicente do Sul (12); Tupanciretã (13); Unistalda (14).

\section{Climate data}

The maximum and minimum temperature values and precipitation data for the period from 2010 to 2012 were obtained from the meteorological station of the National Meteorological Institute (INMET), located in the western-central region of Rio Grande do Sul.

\section{Statistical analysis}

The mean efficacy of acaricides was analyzed using ANOVA and Tukey's test, by means of the GraphPad Prism 5 software. P values $<0.05$ were considered statistically significant.

\section{Results}

Based on the results from the present study, seven of the products analyzed in the western-central region of Rio Grande do Sul, Brazil, exhibited mean efficacy values of less than $95 \%$. The products that were not used in combinations (amitraz $0.250 \mathrm{mg} / \mathrm{mL}$, amitraz
$0.500 \mathrm{mg} / \mathrm{mL}$ and cypermethrin) exhibited mean efficacy values of $54.12 \%, 66.17 \%$ and $65.05 \%$, respectively. On the other hand, the products formulated with combinations of active principles exhibited higher levels of efficiency (amitraz + chlorpyrifos, $80 \%$; cypermethrin + chlorpyrifos + citronella, $87 \%$; ethion + cypermethrin, 91\%; cypermethrin + dichlorvos, $83 \%$; citronella + cypermethrin + chlorpyrifos + piperonyl butoxide, 96\%; and chlorpyrifos + cypermethrin, 100\%) (Table 1).

Amitraz $(0.250 \mathrm{mg} / \mathrm{mL})$ and cypermethrin presented lower efficacy than that of the combinations of cypermethrin + citronellal + chlorpyrifos + piperonyl butoxide and chlorpyrifos + cypermethrin $(\mathrm{p}<0.05)$ (Table 1$)$

The distribution of the results revealed that there was great disparity among the products tested, with nine of the products analyzed exhibiting satisfactory acaricidal efficacy (> 95\%) and acaricidal resistance (efficacy $<95 \%$ ) on at least one farm. The exception was the product based on chlorpyrifos + cypermethrin, which was effective (>95\%) on all of the properties tested (Figure 2).

The meteorological data showed that in the summer (December, January and February), the mean maximum temperature (Tmax) over the last three years was $31.3^{\circ} \mathrm{C}$, whereas the mean minimum 
temperature (Tmin) was $20.2^{\circ} \mathrm{C}$. The mean cumulative rainfall was $497.3 \mathrm{~mm}$. In autumn (March, April and May), the Tmax was $26{ }^{\circ} \mathrm{C}$, the Tmin was $14.8{ }^{\circ} \mathrm{C}$ and the mean cumulative rainfall was $307.7 \mathrm{~mm}$. In winter (June, July and August), the Tmax was $19.8^{\circ} \mathrm{C}$, the Tmin was $9.9^{\circ} \mathrm{C}$ and the mean cumulative rainfall was $352 \mathrm{~mm}$. Finally, in spring (September, October and November), the Tmax, Tmin and mean cumulative rainfall were $25.7^{\circ} \mathrm{C}, 14.4^{\circ} \mathrm{C}$ and $385.7 \mathrm{~mm}$, respectively (Figure 3).

\section{Discussion}

The results from the present study showed that these farms in the western-central region of Rio Grande do Sul, Brazil, face problems with unsatisfactory acaricides against $R$. (B.) microplus (Table 1). Parasite resistance has been observed in several regions of Brazil, as well as in other countries. In Mato Grosso do Sul, twelve commercial acaricides were assessed covering seven active

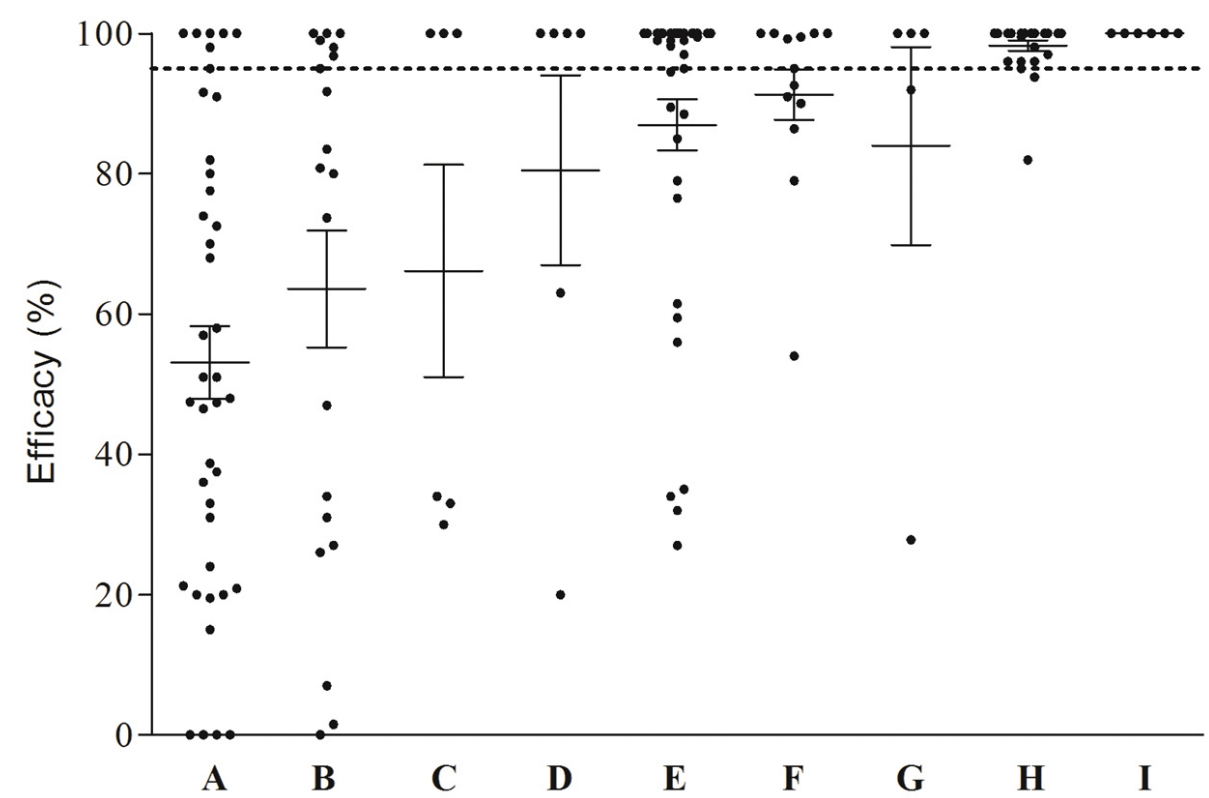

Figure 2. Distribution of acaricidal efficacy of different chemicals on farms in the western-central region of Rio Grande do Sul, Brazil. Lines indicate mean and standard error: amitraz $0.250 \mathrm{mg} / \mathrm{mL}(\mathrm{A})$; cypermethrin $0.150 \mathrm{mg} / \mathrm{mL}(\mathrm{B})$; amitraz $0.500 \mathrm{mg} / \mathrm{mL}(\mathrm{C}) ; \mathrm{amitraz} 1 \mathrm{mg} /$ $\mathrm{mL}+$ chlorpyrifos $1 \mathrm{mg} / \mathrm{mL}$ (D); cypermethrin $0.188 \mathrm{mg} / \mathrm{mL}$ + citronellal $0.013 \mathrm{mg} / \mathrm{mL}+$ chlorpyrifos $0.313 \mathrm{mg} / \mathrm{mL}$ (E); cypermethrin 0.080 $\mathrm{mg} / \mathrm{mL}$ + ethion $0.600 \mathrm{mg} / \mathrm{mL}$ (F); cypermethrin $0.125 \mathrm{mg} / \mathrm{mL}+$ dichlorvos $1.125 \mathrm{mg} / \mathrm{mL}$ (G); cypermethrin $0.188 \mathrm{mg} / \mathrm{mL}+$ citronellal 0.013 $\mathrm{mg} / \mathrm{mL}+$ chlorpyrifos $0.313 \mathrm{mg} / \mathrm{mL}+$ piperonyl butoxide $0.188 \mathrm{mg} / \mathrm{mL}(\mathrm{H})$ and chlorpyrifos $0.825 \mathrm{mg} / \mathrm{mL}+$ cypermethrin $0.099 \mathrm{mg} / \mathrm{mL}$ (I) .

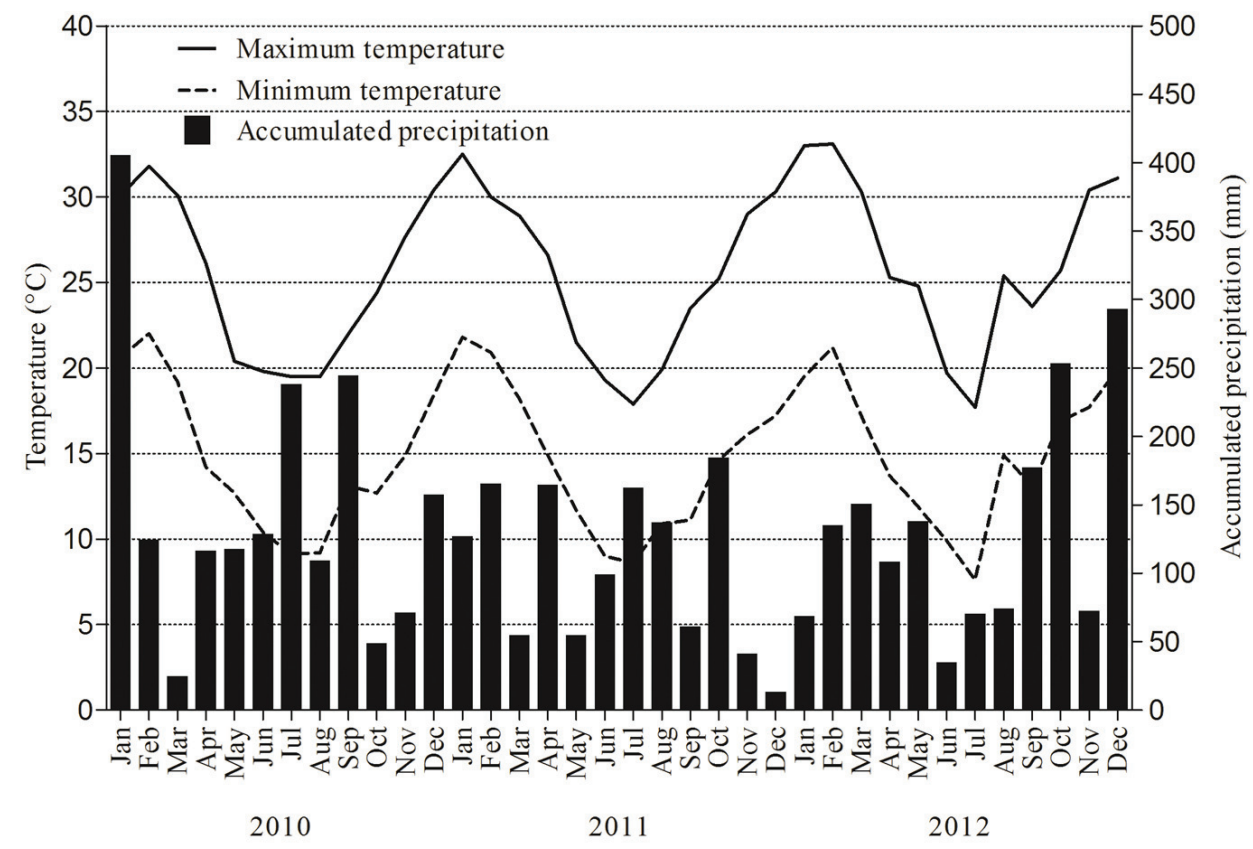

Figure 3. Climatic variation in the western-central region of Rio Grande do Sul, Brazil, between 2010 and 2012. 
Table 1. Efficacy and frequency analysis of acaricides in farms of the western-central region of Rio Grande do Sul, Brazil.

\begin{tabular}{lccccccccc}
\hline & A & B & C & D & E & F & G & H & I \\
\hline Number of Farms & 41 & 21 & 06 & 06 & 39 & 13 & 05 & 28 & 08 \\
Minimum efficacy (\%) & 00 & 00 & 30 & 20 & 27 & 54 & 27.8 & 42 & 100 \\
25\% Percentile & 22.63 & 29 & 32.25 & 52.25 & 85 & 88.20 & 59.9 & 96.25 & 100 \\
Maximum efficacy (\%) & 100 & 100 & 100 & 100 & 100 & 100 & 100 & 100 & 100 \\
Mean efficacy (\%) & $54.12^{\mathrm{a}}$ & $65.05^{\mathrm{ab}}$ & $66.17^{\mathrm{abc}}$ & $80.50^{\mathrm{abc}}$ & $87.17^{\mathrm{bc}}$ & $91.29^{\mathrm{bc}}$ & $83.96^{\mathrm{abc}}$ & $96.26^{\mathrm{c}}$ & $100^{\mathrm{c}}$ \\
Standard Error & 5.16 & 8.06 & 15.14 & 13.52 & 3.55 & 3.59 & 14.13 & 2.12 & 00 \\
Lower 95\% CI & 43.68 & 48.23 & 27.25 & 45.73 & 79.98 & 83.45 & 44.74 & 91.90 & 100 \\
Upper 95\% CI & 64.56 & 81.87 & 105.1 & 115.3 & 94.37 & 99.12 & 123.2 & 100.60 & 100 \\
\hline
\end{tabular}

Distinct letters in the column indicate statistical differences by Tukey's test $(p<0.05)$. Amitraz $\left(0.250 \mathrm{mg} \mathrm{mL}^{-1}\right)(\mathrm{A})$; cypermethrin $\left(0.150 \mathrm{mg} \mathrm{mL}^{-1}\right)(\mathrm{B})$; amitraz $\left(0.500 \mathrm{mg} \mathrm{mL}^{-1}\right)(\mathrm{C})$; amitraz $\left(1 \mathrm{mg} \mathrm{mL}^{-1}\right)+$ chlorpyrifos $\left(1 \mathrm{mg} \mathrm{mL}^{-1}\right)(\mathrm{D})$; cypermethrin $\left(0.188 \mathrm{mg} \mathrm{mL}^{-1}\right)+$ citronellal $\left(0.013 \mathrm{mg} \mathrm{mL}^{-1}\right)+$ chlorpyrifos $\left(0.313 \mathrm{mg} \mathrm{mL}^{-1}\right)$ (E); cypermethrin $\left(0.080 \mathrm{mg} \mathrm{mL}^{-1}\right)+$ ethion $\left(0.600 \mathrm{mg} \mathrm{mL}^{-1}\right)(\mathrm{F})$; cypermethrin $\left(0.125 \mathrm{mg} \mathrm{mL}^{-1}\right)+$ dichlorvos $\left(1.125 \mathrm{mg} \mathrm{mL}^{-1}\right)(\mathrm{G})$; cypermethrin $\left(0.188 \mathrm{mg} \mathrm{mL}^{-1}\right)+$ citronellal $\left(0.013 \mathrm{mg} \mathrm{mL}^{-1}\right)+$ chlorpyrifos $\left(0.313 \mathrm{mg} \mathrm{mL}^{-1}\right)+$ piperonyl butoxide $\left(0.188 \mathrm{mg} \mathrm{mL}^{-1}\right)(\mathrm{H})$ and chlorpyrifos $\left(0.825 \mathrm{mg} \mathrm{mL}^{-1}\right)+$ cypermethrin $\left(0.099 \mathrm{mg} \mathrm{mL}^{-1}\right)(\mathrm{I})$.

agents (singly or in combination). Of these, only one did not exhibit acaricide resistance on at least one farm (GOMES et al., 2011). In São Paulo, Mendes et al. (2011) observed resistance to products based on cypermethrin, deltamethrin and chlorpyrifos. In India, Sharma et al. (2012) observed the presence of resistant strains on $66.6 \%$ of the farms analyzed in different regions of the country. In Mexico, resistance to cypermethrin was observed in $32.6 \%$ of the farms by Rodriguez-Vivas et al. (2012), using the larval packet test (LPT).

In the southwestern and southeastern regions of Rio Grande do Sul, Brazil, low susceptibility of acaricides against $R$. (B.) microplus has been reported for amidines, pyrethroids and organophosphates (VARGAS et al., 2003; SANTOS et al., 2008; FARIAS et al., 2008). In addition, recently in the metropolitan region of Porto Alegre, Brazil, a strain of ticks resistant to cypermethrin, chlorpyrifos, fipronil, amitraz and ivermectin was detected (RECK et al., 2014).

However, parasite resistance to acaricides is widespread in many countries and regions of Brazil, including the western-central region of Rio Grande do Sul, Brazil, for which there were no previous reports of acaricide resistance. Therefore, more appropriate control measures are required for combating $R$. (B.) microplus, in order to delay the onset of multiple resistance on farms.

The products with single active agents (amitraz $0.250 \mathrm{mg} /$ $\mathrm{mL}$, amitraz $0.500 \mathrm{mg} / \mathrm{mL}$ and cypermethrin) exhibited the lowest efficiency levels on the farms of the region studied. Amitraz $(0.250 \mathrm{mg} / \mathrm{mL})$ exhibited values lower $(\mathrm{P}<0.05)$ than those of the other products assessed (Table 1, Figure 2). Products with combinations of active ingredients exhibited higher efficiency levels, with more than $75 \%$ of the samples $\left(25^{\text {th }}\right.$ percentile) ranging from $80 \%$ to $100 \%$ effectiveness, for the products cypermethrin + chlorpyrifos + citronella, ethion + cypermethrin, citronella + cypermethrin + chlorpyrifos + piperonyl butoxide and chlorpyrifos + cypermethrin (Table 1, Figure 2). These results indicate the importance of using a combination of active agents to obtain satisfactory efficiency in areas where the parasite is resistant to the active agent in isolation, as has also been recommended for controlling other parasites that have multiple resistance (CEZAR et al., 2011). However, this must be conducted with the support of epidemiological information, farm management and previous results from acaricidal efficacy tests, thereby avoiding the onset of resistance to all commercial products.
There was considerable disparity among the acaricide efficiency results from different farms in the same region (Figure 2), thus demonstrating that acaricidal efficacy is highly variable, depending on the management system adopted on each farm, particularly in terms of the frequency of acaricide use (ROCHA et al., 2011b). It is also known that infestation by $R$. (B.) microplus is distributed according to certain factors, such as peripartum, pregnancy and lactation for non-pregnant cows. Furthermore, Bos taurus cattle are more susceptible than Bos indicus, as are cows with greater levels of milk production and lactation. Cows kept at high and medium stocking densities are more susceptible to infestation than are those at low stocking densities (SILVA et al., 2013).

Other factors, such as climatic conditions, especially relative humidity and temperature, influence the level of cattle infestation by ticks. Temperatures below $14^{\circ} \mathrm{C}$ and greater than $40{ }^{\circ} \mathrm{C}$ impair the development of $R$. (B.) microplus eggs (CORSON et al., 2004; SUTHERST; BOURNE, 2006). The western-central region of Rio Grande do Sul, Brazil, has a mean annual temperature of $19{ }^{\circ} \mathrm{C}$ and mean annual rainfall of between $1400-1800 \mathrm{~mm}$ (BECKER et al., 2012). Severe changes occur, depending on the season, as can be seen from the mean maximum and minimum temperatures (Figure 3). The climatic conditions are often within the development threshold of $R$. (B.) microplus. Consequently, there is a need to use chemical treatment during specific periods, combining anti-parasite treatment with environmental factors, in order to reduce the possibility of development of ticks and environmental infestation.

\section{Conclusion}

In the western-central region of Rio Grande do Sul, Brazil, $R$. (B.) microplus populations have variable degrees of susceptibility to different acaricides, thus suggesting that resistance to the active compounds exists. Treatment against this ixodid should be performed taking into consideration the climatic variation that occurs in this region, preferably when the chemical action is coupled with environmental action (winter, summer). In addition, the choice of product to be used should be based on the results from acaricide efficacy tests. 


\section{References}

Almeida MBD, Tortelli FP, Riet-Correa B, Ferreira JLM, Soares MP, Farias NAR, et al. Tick fever in southern Brazil: a retrospective study of 1978-2005. Pesq Vet Bras 2006; 26(4): 237-242.

Anualpec: anuário da pecuária brasileira. São Paulo: FNP Consultoria \& Comércio; 2012.

Becker ELS, Buriol GA, Streck NA. Climate and Weathering the Formation of the Soils in Rio Grande do Sul State, Brazil. Rev Bras Geo Fis 2012; 5(1): 33-46.

Castro-Janer E, Rifran L, Piaggio J, Gil A, Miller RJ, SchumakerTTS. In vitro tests to establish LC50 and discriminating concentrations for fipronil against Rhipicephalus (Boophilus) microplus (Acari: Ixodidae) and their standardization. Vet Parasitol2009; 162(1-2): 120-128. PMid:19278787. http://dx.doi.org/10.1016/j.vetpar.2009.02.013

Cezar AS, Ribas HO, Pivoto FL, Sangioni LA, Vogel FSF. Combinação de drogas antiparasitárias como uma alternativa para o controle de nematódeos gastrintestinais multirresistentes em ovinos. Pesq Vet Bras 2011; 31(2): 151-157. http://dx.doi.org/10.1590/S0100736X2011000200010

Corson MS, Teel PD, Grant WE. Microclimate influence in a physiological model of cattle-fever tick (Boophilus spp.) population dynamics. Ecol Model 2004; 180(4): 487-514. http://dx.doi. org/10.1016/j.ecolmodel.2004.04.034

Drummond RO, Ernst SE, Trevino JL, Gladney WJ, Graham OH. Boophilus annulatus and B. microplus: laboratory tests of insecticides. $J$ Econ Entomol 1973; 66(1): 130-133. Available from: http://www.ncbi. nlm.nih.gov/pubmed/4690254 PMid:4690254.

Farias NA, Ruas JL, Santos TRBD. Análise da eficácia de acaricidas sobre o carrapato Boophilus microplus, durante a última década, na região sul do Rio Grande do Sul. Cienc Rural 2008; 38(6): 1700-1704. http://dx.doi. org/10.1590/S0103-84782008000600032

Gomes A, Koller WW, Barros ATMD. Suscetibilidade de Rhipicephalus (Boophilus) microplus a carrapaticidas em Mato Grosso do Sul, Brasil. Cienc Rural 2011; 41(8): 1447-1452. http://dx.doi.org/10.1590/S010384782011005000105

GrafJF, Gogolewski R, Leach-Bing N, Sabatini GA, Molento MB, Bordin EL, et al. Tick control: an industry point of view. Parasitology 2004; 129(Suppl): S427-S442. PMid:15938522. http://dx.doi.org/10.1017/ S0031182004006079

Guerrero FD, Lovis L, Martins JR. Acaricide resistance mechanisms in Rhipicephalus (Boophilus) microplus. Rev Bras Parasitol Vet 2012; 21(1): 1-6. PMid:22534937. http://dx.doi.org/10.1590/S198429612012000100002

Jonsson NN. The productivity effects of cattle tick (Boophilus microplus) infestation on cattle, with particular reference to Bos indicus cattle and their crosses. Vet Parasitol 2006; 137(1-2): 1-10. PMid:16472920. http:// dx.doi.org/10.1016/j.vetpar.2006.01.010

Klafke GM, Sabatini GA, Albuquerque TA, Martins JR, Kemp DH, Miller RJ, et al. Larval immersion tests with ivermectin in populations of the cattle tick Rhipicephalus (Boophilus) microplus (Acari: Ixodidae) from State of Sao Paulo, Brazil. Vet Parasitol 2006; 142(3-4): 386-390. PMid:16904265. http://dx.doi.org/10.1016/j.vetpar.2006.07.001

Lovis L, Perret JL, Bouvier J, Fellay JM, Kaminsky R, Betschart B, et al. A new in vitro test to evaluate the resistance level against acaricides of the cattle tick, Rhipicephalus (Boophilus) microplus. Vet Parasitol 2011; 182(2-4): 269-280. PMid:21741175. http://dx.doi.org/10.1016/j. vetpar.2011.06.004
Mendes MC, Lima CKP, Nogueira AHC, Yoshihara E, Chiebao DP, Gabriel FHL, et al. Resistance to cypermethrin, deltamethrin and chlorpyriphos in populations of Rhipicephalus (Boophilus) microplus (Acari: Ixodidae) from small farms of the State of São Paulo, Brazil. Vet Parasitol 2011; 178(3-4): 383-388. PMid:21306827. http://dx.doi. org/10.1016/j.vetpar.2011.01.006

Reck J, Klafke GM, Webster A, Dall'Agnol B, Scheffer R, Souza UA, et al. First report of fluazuron resistance in Rhipicephalus microplus: a field tick population resistant to six classes of acaricides. Vet Parasitol 2014; 201(1-2): 128-136. PMid:24560364. http://dx.doi.org/10.1016/j. vetpar.2014.01.012

Rocha CMBMD, Leite RC, Bruhn FRP, Guimarães AM, Furlong J. Perceptions about the biology of Rhipicephalus (Boophilus) microplus among milk producers in Divinópolis, Minas Gerais. Rev Bras Parasitol Vet 2011a; 20(4): 289-294. PMid:22166382. http://dx.doi.org/10.1590/ S1984-29612011000400006

Rocha CMBMD, Leite RC, Bruhn FRP, Guimarães AM, Furlong J. Perceptions of milk producers from Divinópolis, Minas Gerais, regarding Rhipicephalus (Boophilus) microplus control. Rev Bras Parasitol Vet 2011b; 20(4): 295-302. PMid:22166383. http://dx.doi.org/10.1590/S198429612011000400007

Rodriguez-Vivas RI, Hodgkinson JE, Rosado-Aguilar JA, Villegas-Perez SL, Trees AJ. The prevalence of pyrethroid resistance phenotype and genotype in Rhipicephalus (Boophilus) microplus in Yucatan, Mexico. Vet Parasitol 2012; 184(2-4): 221-229. PMid:21978740. http://dx.doi. org/10.1016/j.vetpar.2011.09.017

Sabatini GA, Kemp DH, Hughes S, Nari A, Hansen J. Tests to determine LC50 and discriminating doses for macrocyclic lactones against the cattle tick, Boophilus microplus. Vet Parasitol 2001; 95(1): 53-62. Available from: http://www.ncbi.nlm.nih.gov/pubmed/11163698 http://dx.doi. org/10.1016/S0304-4017(00)00406-4

Santarém VA, Sartor IF. The free-living phase and seasonal variation of Boophilus microplus in Botucatu, São Paulo State, Brazil. Semin. Cienc. Agrar. 2003; 24(1): 11-19. Available from: http://www.uel.br/revistas/ uel/index.php/semagrarias/article/viewArticle/2111

Santos TRB, Farias NAR, Cunha-Filho NA, Vaz IS Jr. Uso de acaricidas em Rhipicephalus (B.) microplus de duas regiões fisiográficas do Rio Grande do Sul. Acta Sci Vet 2008; 36(1): 25-30. Available from: http:// www.ufrgs.br/actavet/36-1/036-1.htm

Sharma AK, Kumar R, Kumar S, Nagar G, Singh NK, Rawat SS, et al. Deltamethrin and cypermethrin resistance status of Rhipicephalu (Boophilus) microplus collected from six agro-climatic regions of India. Vet Parasitol 2012; 188(3-4): 337-345. PMid:22541585. http://dx.doi. org/10.1016/j.vetpar.2012.03.050

Silva JBD, Rangel CP, Azevedo Baêta B, Fonseca AH. Influence of the physiological state on infestation by Rhipicephalus microplus in dairy cows. Ticks Tick Borne Dis 2013; 4(1-2): 52-56. PMid:23238247. http:// dx.doi.org/10.1016/j.ttbdis.2012.07.003

Sutherst RW, Bourne AS. The effect of desiccation and low temperature on the viability of eggs and emerging larvae of the tick, Rhipicephalus (Boophilus) microplus (Canestrini) (Ixodidae). Int J Parasitol 2006; 36(2): 193-200. PMid:16300766. http://dx.doi.org/10.1016/j. ijpara.2005.09.007

Vargas MS, Céspedes NS, Sánchez HF, Martins JR, Céspedes COC. Avaliação in vitro de uma cepa de campo de Boophilus microplus (Acari: Ixodidae) resistente à Amitraz. Cienc Rural 2003; 33(4): 737-742.

Wall R. Ectoparasites: future challenges in a changing world. Vet Parasitol 2007; 148(1): 62-74. PMid:17560724. http://dx.doi.org/10.1016/j. vetpar.2007.05.011 